TITLE:

\title{
Distributional changes in branchial chloride cells during freshwater adaptation in Japanese sea bass Lateolabrax japonicus
}

\section{AUTHOR(S):}

Hirai, Narisato; Tagawa, Masatomo; Kaneko, Toyoji; Seikai, Tadahisa; Tanaka, Masaru

\section{CITATION:}

Hirai, Narisato ...[et al]. Distributional changes in branchial chloride cells during

freshwater adaptation in Japanese sea bass Lateolabrax japonicus. Zoological Science 1999, 16(1): 43-49

\section{ISSUE DATE:}

1999-02

URL:

http://hdl.handle.net/2433/57228

RIGHT:

(c) 日本動物学会 / Zoological Society of Japan 


\title{
Distributional Changes in Branchial Chloride Cells during Freshwater Adaptation in Japanese Sea Bass Lateolabrax japonicus
}

\author{
Narisato Hirai ${ }^{1 *}$, Masatomo Tagawa ${ }^{1}$, Toyoji Kaneko² \\ Tadahisa Seikai $^{3}$ and Masaru Tanaka ${ }^{1}$ \\ ${ }^{1}$ Division of Applied Biosciences, Graduate School of Agriculture, Kyoto University, \\ Kitashirakawa, Kyoto 606-8502, Japan \\ ${ }^{2}$ Ocean Research Institute, University of Tokyo, Minamidai, Nakano, Tokyo 164-8639, Japan \\ ${ }^{3}$ Fisheries Research Station, Graduate School of Agriculture, Kyoto University, \\ Maizuru, Kyoto 625-0086, Japan
}

\begin{abstract}
Distributional changes in branchial chloride cells were examined in Japanese sea bass (Lateolabrax japonicus) juveniles transferred from seawater (SW) to fresh water (FW) during their migration season toward low salinity habitat in nature. Chloride cells were identified by immunocytochemistry with a specific antiserum for $\mathrm{Na}^{+}, \mathrm{K}^{+}$-ATPase. In fish reared in SW as controls, branchial chloride cells were localized exclusively in the filaments and absent in the lamellae. When sea bass were transferred from SW to FW, chloride cells emerged in gill lamellae, starting at the proximal part of the lamellae and thereafter spread over the lamellar epithelium. On 7th and 15th days after FW transfer, chloride cells were mostly found on the lamellae, whereas the number of filament chloride cells was decreased. These results suggest that, in Japanese sea bass juveniles, chloride cells in the gill lamellae are important in FW adaptation, and that lamellar chloride cells originated from the filaments and migrated to the lamellae during FW adaptation.
\end{abstract}

\section{INTRODUCTION}

Teleost fish maintain ionic and osmotic gradients between the body fluid and external environments (Evans, 1984). In both freshwater (FW) and seawater (SW) fish, plasma osmolality is usually maintained at narrow physiological ranges, which are about one third of SW osmolality. The gills, kidney and intestine are important osmoregulatory organs, creating ionic and osmotic gradients. In particular, chloride cells mainly present in the gills are best known as the salt-secreting site in SW fish (Foskett and Scheffey, 1982; Zadunaiskey, 1984; Avella and Bornancin, 1990). Chloride cells are characterized by the presence of numerous mitochondria and an extensive tubular system. The tubular system is continuous with the basolateral membrane, resulting in the large surface area for the placement of ion-transporting proteins, such as $\mathrm{Na}^{+}, \mathrm{K}^{+}-$ ATPase (Karnakey et al., 1976; Zadunaiskey, 1984; McCormick, 1995). In contrast to their salt-secreting function in SW, osmoregulatory functions of chloride cells in FW are still poorly understood. Chloride cells have been suggested to be in charge of ion uptake in FW to compensate for diffusional ion losses in hypoosmotic environments (McCormick

\footnotetext{
* Corresponding author: Tel. +75-753-6225; FAX. +75-753-6229.
}

et al., 1992; Flik et al., 1996), although direct evidence for this is still lacking.

In salmonids and eel, two distinct types of chloride cells are detected in filament and lamellar epithelia in the gills (Avella and Bornancin, 1990; Uchida et al., 1996; Sasai et al., 1998). In chum salmon fry, filament chloride cells are activated following transfer from FW to SW, whereas lamellar cells are frequently observed in FW, but disappear after SW transfer (Uchida et al.,1996). These findings suggest that filament and lamellar chloride cells are important in adaptation to SW and FW, respectively; filament chloride cells are considered to be the site for salt secretion in SW, and lamellar chloride cells are presumably responsible for ion uptake in FW.

Japanese sea bass Lateolabrax japonicus is an euryhaline marine fish inhabiting coastal areas and estuaries in Japan, and occasionally appears in FW (Ochiai and Tanaka, 1986). As is the case with other marine teleosts, eggs are spawned in SW; however, the advanced larvae are often found in brackish water zones such as estuaries (Matsumiya et al., 1982, 1985; Fujita et al., 1988). In fact, their amphydromous characteristics are pointed out in some population (Tanaka, 1997); they immigrate to FW at the larva-juvenile transformation phase or early juvenile stage. Therefore, in contrast to other marine teleosts so far examined, Japanese sea bass is expected to acquire the ability for FW adaptation during their 
early life stages.

Considering the unique FW adaptability, Japanese sea bass would be a good experimental model to explore the functions of chloride cells in FW. In this study, changes in distribution and density of branchial chloride cells were investigated following transfer from SW to FW in Japanese sea bass at their potential FW entry stage. Our observations indicated that chloride cells emerged in the gill lamellae after FW transfer, and that those lamellar chloride cells originated from the gill filaments and migrated to the lamellae during FW adaptation.

\section{MATERIALS AND METHODS}

\section{Fish rearing and transfer experiments}

Artificially fertilized eggs of sea bass were obtained from Chiba Prefectural Tokyo Bay Fish Farming Center, and transported to Fisheries Research Station, Kyoto University, on January 16, 1997. They were reared in a stock tank (500-I) with filtered SW at $15^{\circ} \mathrm{C}$. After hatching on January 17, larvae were fed on rotifers Brachionus plicatilis, Artemia sp. nauplii and artificial diet according to their developmental stages until 103 days after hatching when the transfer experiment started. Three tanks with closed filtering systems were filled with FW (0 ppt salinity), diluted SW (11 ppt) or SW (33 ppt). Seventy juveniles (juvenile stage; total length, $40 \mathrm{~mm}$; wet weight, $700 \mathrm{mg}$ ) were directly transferred to each tank, reared at $18-22^{\circ} \mathrm{C}$ under the natural photoperiod. Dead fish were counted daily and removed.

Ten fish from each tank were sampled on 0 day, 1 day, 3 days, 7 days and 15 days after transfer (days $0,1,3,7$ and 15). After anesthesia with MS-222, the gills were removed and fixed in 4\% paraformaldehyde in $0.1 \mathrm{M}$ phosphate buffer $\left(\mathrm{pH} \mathrm{7.4)}\right.$ for $24 \mathrm{hrs}$ at $4^{\circ} \mathrm{C}$, and preserved in $70 \%$ ethanol at $4^{\circ} \mathrm{C}$.
Immunocytochemical detection of gill chloride cells

The second gill arch was removed, dehydrated in ethanol and embedded in paraffin. Serial sections $(5 \mu \mathrm{m})$ were cut parallel to the long axis of the filament, and mounted on slides. Branchial chloride cells were detected immunocytochemically with an antiserum specific for $\mathrm{Na}^{+}, \mathrm{K}^{+}$-ATPase, which was raised against a synthetic peptide corresponding to part of the highly conserved region of the $\mathrm{Na}^{+}, \mathrm{K}^{+}$ATPase $\alpha$-subunit (Ura et al., 1996). The sections were immnocytochemically stained by the avidin-biotin-peroxidase complex (ABC) method (Hsu et al., 1981) using a commercial kit (DAKO sABC kit, Glostrup, Denmark). The deparaffined sections were incubated sequentially with: (1) $0.3 \% \mathrm{H}_{2} \mathrm{O}_{2}$ for $60 \mathrm{~min}$, (2) $5 \%$ normal goat serum for $60 \mathrm{~min},(3)$ anti-Na+ $\mathrm{Na}^{+} \mathrm{K}^{+}$-ATPase serum diluted 1:2000 for $20 \mathrm{hr}$ at $4^{\circ} \mathrm{C}$, (4) biotinylated anti-rabbit IgG for $30 \mathrm{~min}$, (5) ABC for 30 $\mathrm{min}$, and (6) $0.01 \% 3,3$ '-diaminobenzidine tetrahydrochloride containing $0.005 \% \mathrm{H}_{2} \mathrm{O}_{2}$ for 8 min.

For Quantitative analyses, the density of chloride cells was measured. Immnoreactive cells were classified into lamellar chloride cells when more than $50 \%$ of the sectional area was on a lamellae, and into filament chloride cells in other cases. Our preliminary observations and a previous study (Laurent and Dunel, 1980) have indicated that chloride cells in the filament were more abundant on the afferent vascular side than on the efferent. To overcome the uneven distribution of chloride cells in the gills and to minimize the counting loss, the analysis was made on the central zone of the filament, which had the full length of the lamella. All immunoreactive cells in the filaments and lamellae were counted along 700-1000 $\mu \mathrm{m}$ length of a filament, and the density was expressed as cell number/mm gill filament. Since the length of lamella varied among individual fish, and moreover, no tendency among treatment groups was found, the locations of chloride cells were expressed as relative values. To represent the relative location of lamellar chloride cells to the filament, the distance from a chloride cell to the filament $(D)$ and the total length of the lamella $(L)$ were measured on the section, as shown in Fig. 1. The relative distance to the filament was calculated as D $\times 100 / L(\%)$.

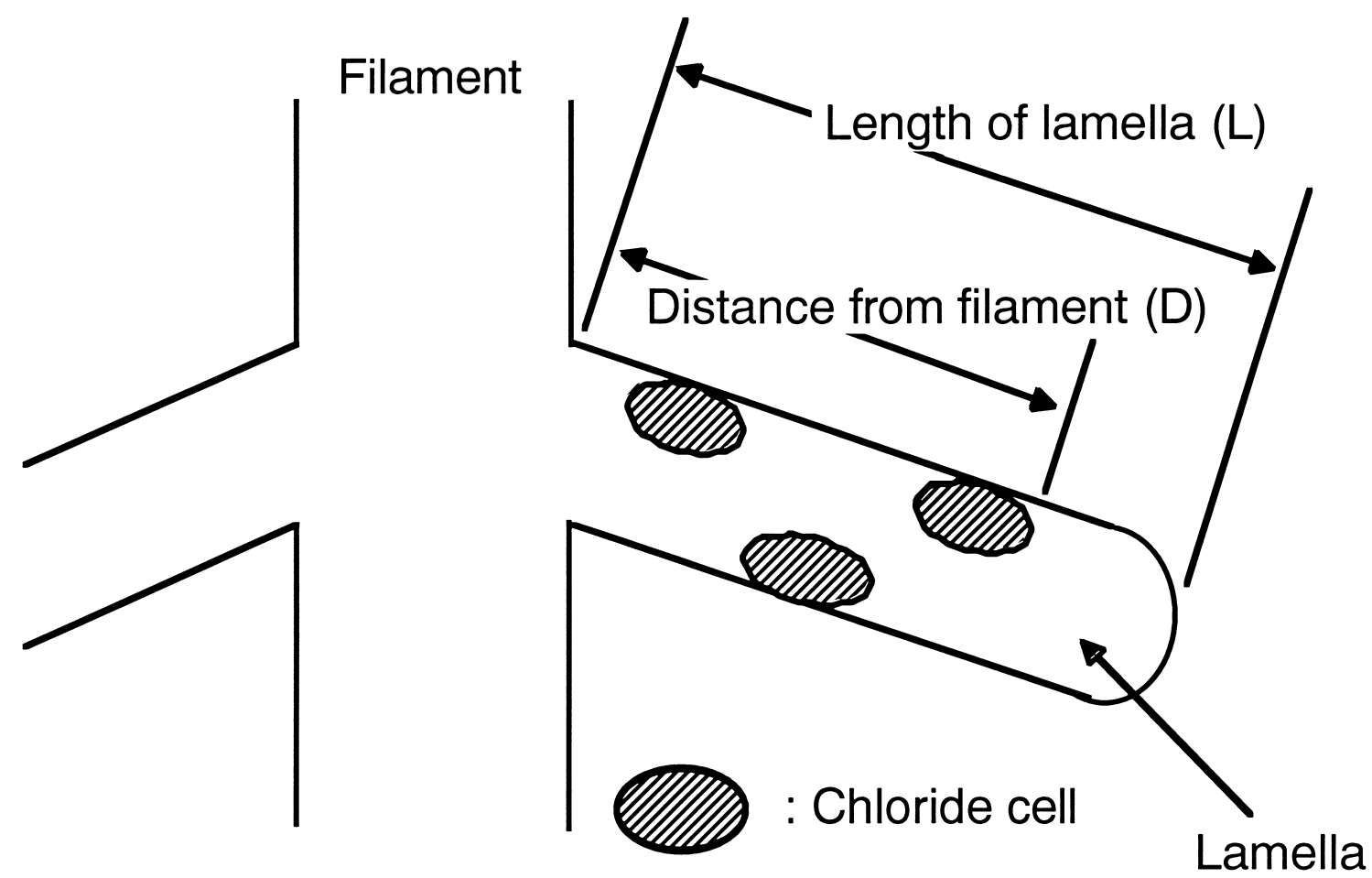

Fig. 1. Schematic drawing of a gill filament and lamella. To represent the relative location of lamellar chloride cells to the filament, a relative distance was calculated as $\mathrm{D} \times 100 / \mathrm{L}(\%)$. 
Data for chloride cells density were shown as the mean \pm S.E.M. Significance of differences was determined by the Student's t-test after variance analysis by F-test.

\section{RESULTS}

Fig. 2 shows changes in the survival rates after transfer to different salinities. More than $90 \%$ of fish transferred to SW (control) and 1/3 SW survived for 15 days. When transferred to FW, the number of surviving larvae decreased until day 10 ; however, no fish were dead thereafter, the survival rate being $77 \%$ on day 15 .

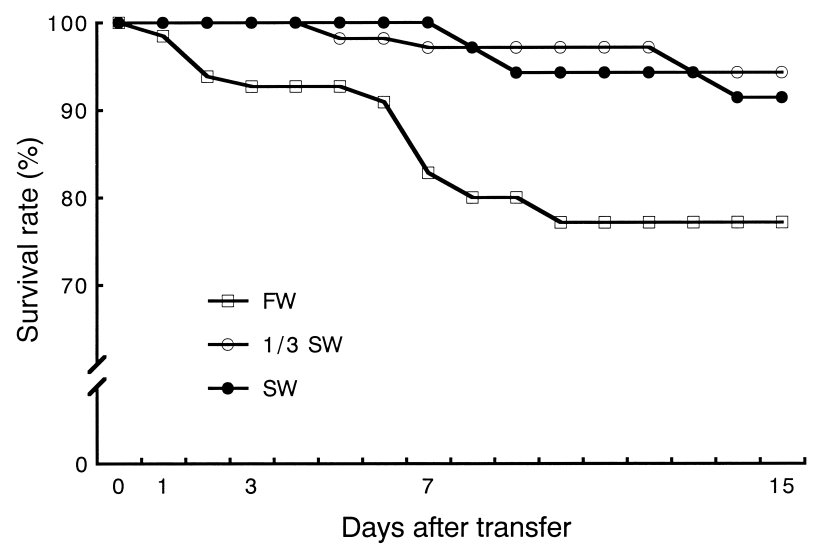

Fig. 2. Changes in survival rates of juvenile Japanese sea bass after transfer to FW, 1/3 SW and SW.

Fig. 3 shows sagittal sections of the gills stained with anti$\mathrm{Na}^{+}, \mathrm{K}^{+}$-ATPase serum to identify chloride cells. Distribution of chloride cells was restricted to the filament epithelia in fish reared in SW (Fig. 3a, b) and those transferred to 1/3 SW (Fig. 3c), and no chloride cells were observed in the lamellae. In fish transferred to FW, however, chloride cells emerged at the proximal part of the lamellae on day 1 (Fig. 3d), and then expanded their distribution over the lamellae on days 3, 7 and 15 (Fig. 3e, f, g).

For quantitative analyses, the density of chloride cells in both filaments and lamellae was measured (Fig. 4). On days 0 and 15 in SW and on day 15 in 1/3 SW, chloride cells were exclusively detected in filaments, and no chloride cells were detectable in the lamellae. When transferred to FW, a few, but significant numbers of, chloride cells appeared in the lamellae as early as day 1 . Thereafter, lamellar chloride cells increased significantly $(p<0.01)$ and predominated over filament cells on days 3, 7 and 15. In sharp contrast, chloride cells in the filaments decreased significantly $(p<0.01)$ following FW transfer.

Changes in chloride cell distribution in the lamellar epithelia following FW transfer are shown in Fig. 5. In SW (day 0), chloride cells were not present in the lamellae. Following FW transfer, lamellar chloride cells were found only in the region close to the filament on day 1 , and then spread out to be distributed over the full length of the lamellae on days 7 and 15.

\section{DISCUSSION}

The most drastic change in the gills of sea bass juveniles transferred from SW to FW is the appearance of chloride cells in the lamellae. All branchial chloride cells were detected in the filaments in fish reared in SW and 1/3 SW, whereas lamellar chloride cells become evident in fish transferred to FW ( Fig. $3)$. The presence of chloride cells in the lamellar epithelia was reported in chum salmon (Uchida et al., 1996) and Japanese eel (Sasai et al., 1998) adapted to FW. Those lamellar chloride cells disappeared when transferred to SW in chum salmon (Uchida et al., 1996). In the present study, after transfer to FW, lamellar chloride cells first appeared at the base close to the filament, and expanded from the proximal to distal part of the lamellae, probably suggesting an unidirectional migration of chloride cells. In chum salmon gills, undifferentiated stem cells and immature chloride cells are often observed in the filaments in close association with the central venus sinus, but not found in the gill lamellae (Uchida and Kaneko, 1996). Cell proliferation was only observed in filaments, and not in lamellae (Laurent et al., 1994). Taken together, lamellar chloride cells appearing after $\mathrm{FW}$ transfer are considered to originate from undifferentiated cells in the filament, and migrate toward the distal part of the lamellae to spread their distribution over the lamellar epithelia. Such a spacial shift of the chloride cell distribution might facilitate a possible ion-transporting function, allowing to expand their apical membrane in contact with external environments.

The juveniles transferred to SW or $1 / 3 \mathrm{SW}$ showed a lower mortality during the first 7 days (Fig. 2), suggesting that the handling stress caused by transfer could be minor. On the contrary, the survival rate decreased to about $80 \%$ in fish transferred to FW. This mortality is probably due to the exposure to the hypoosmotic environment. It is noticeable that a higher mortality was observed only during the first 7 days. On the other hand, the chloride cell distribution reached the maximum expansion over the lamellae, and their density became saturated on day 7 (Figs. 4 and 5). This coincidence suggests that the observed changes in chloride cell distribution during the first 7 days after FW transfer are critical for full adaptation to $\mathrm{FW}$ in juvenile sea bass.

In previous studies, diverse functions of chloride cells have been considered in SW- and FW-adapted fish. The involvement of chloride cells in ion secretion has been demonstrated in SW-adapted fish (Foskett and Scheffey, 1982; Zadunaiskey, 1984; Avella and Bornancin, 1990), whereas chloride cells have been suggested to be involved in ion absorption in FWadapted fish (Perry et al., 1992; Flik et al., 1996; Li et al., 1997), especially in calcium uptake (McCormick et al., 1992; Flik et al., 1995, 1996; Li et al., 1997). On the other hand, morphologically different types of chloride cells were reported by Pisam et al. (1987), who classified filament chloride cells into two types, based on their ultrastructural observations in guppy Lebistes reticulatus. The chloride cells located on the base of gill lamellae were referred to as $\alpha$ type and those on the interlamellar region of the filaments as $\beta$ type. While $\alpha$ 

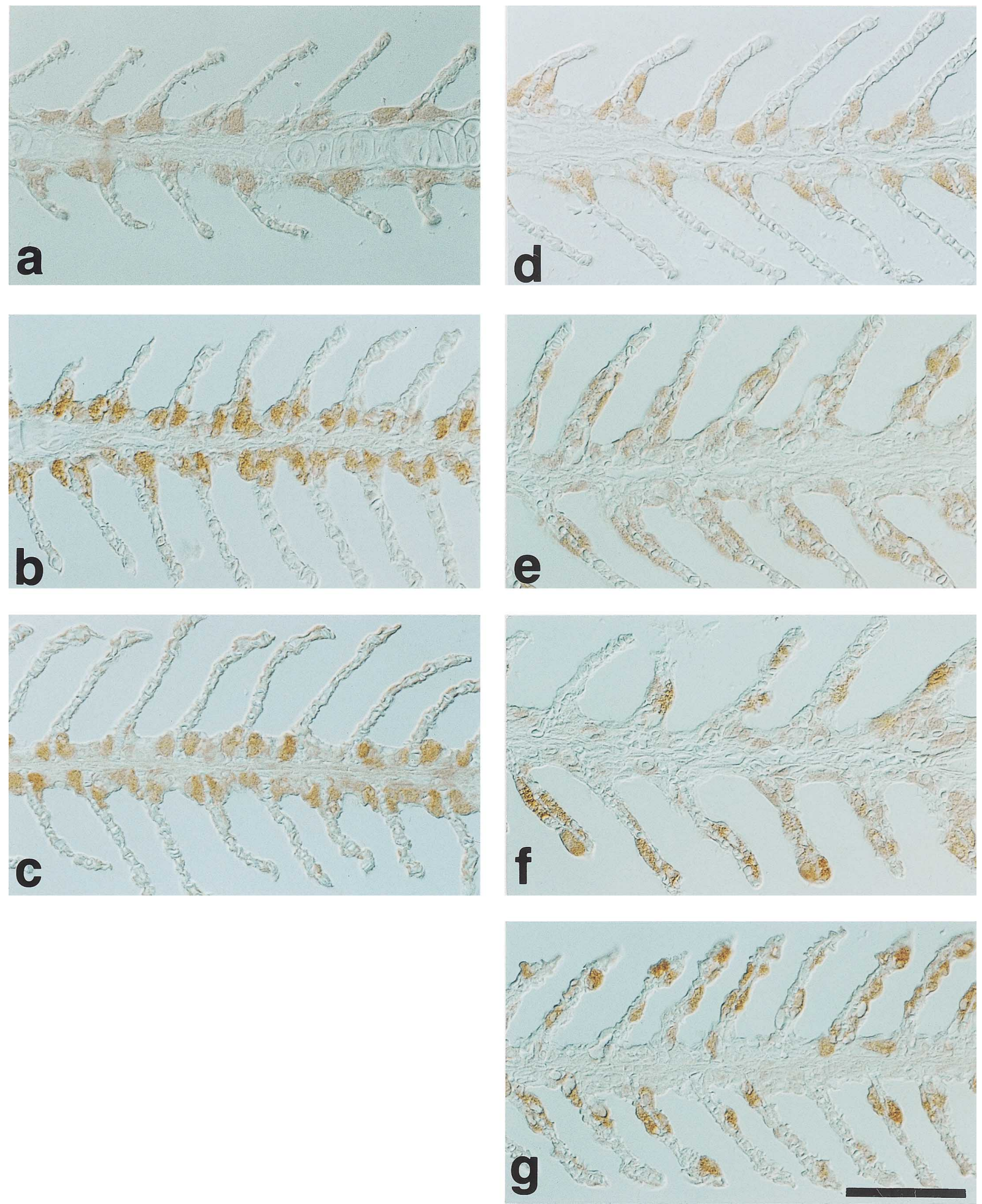

Fig. 3. Sagittal sections of the gills stained with an antiserum specific for $\mathrm{Na}^{+}, \mathrm{K}^{+}-\mathrm{ATPase}$ in Japanese sea bass. $\mathrm{a}$, day 0 in $\mathrm{SW}$; $b$, day 15 in SW; c, day 15 in 1/3 SW; d, day 1 in FW; e, day 3 in FW; f, day 7 in FW; g, day 15 in FW. Bar, $50 \mu$ m.

cells exist in both FW and SW, $B$ cells are only present in FW. The occurrence of $\alpha$ and $B$ cells has also been confirmed in other several teleost species (Pisam et al., 1987, 1990, 1993; Pisam and Rambourg, 1991). Although they claimed that $B$ cells in the interlamellar region of the gill filaments were FW- type chloride cells, it is also possible that $\alpha$-type chloride cells at the base of the lamellae migrate up to the lamellar epithelia in response to FW exposure. This may explain the absence of $\alpha$ cells in FW. Such explanation might also support our finding that FW-type lamellar chloride cells originate from gill 


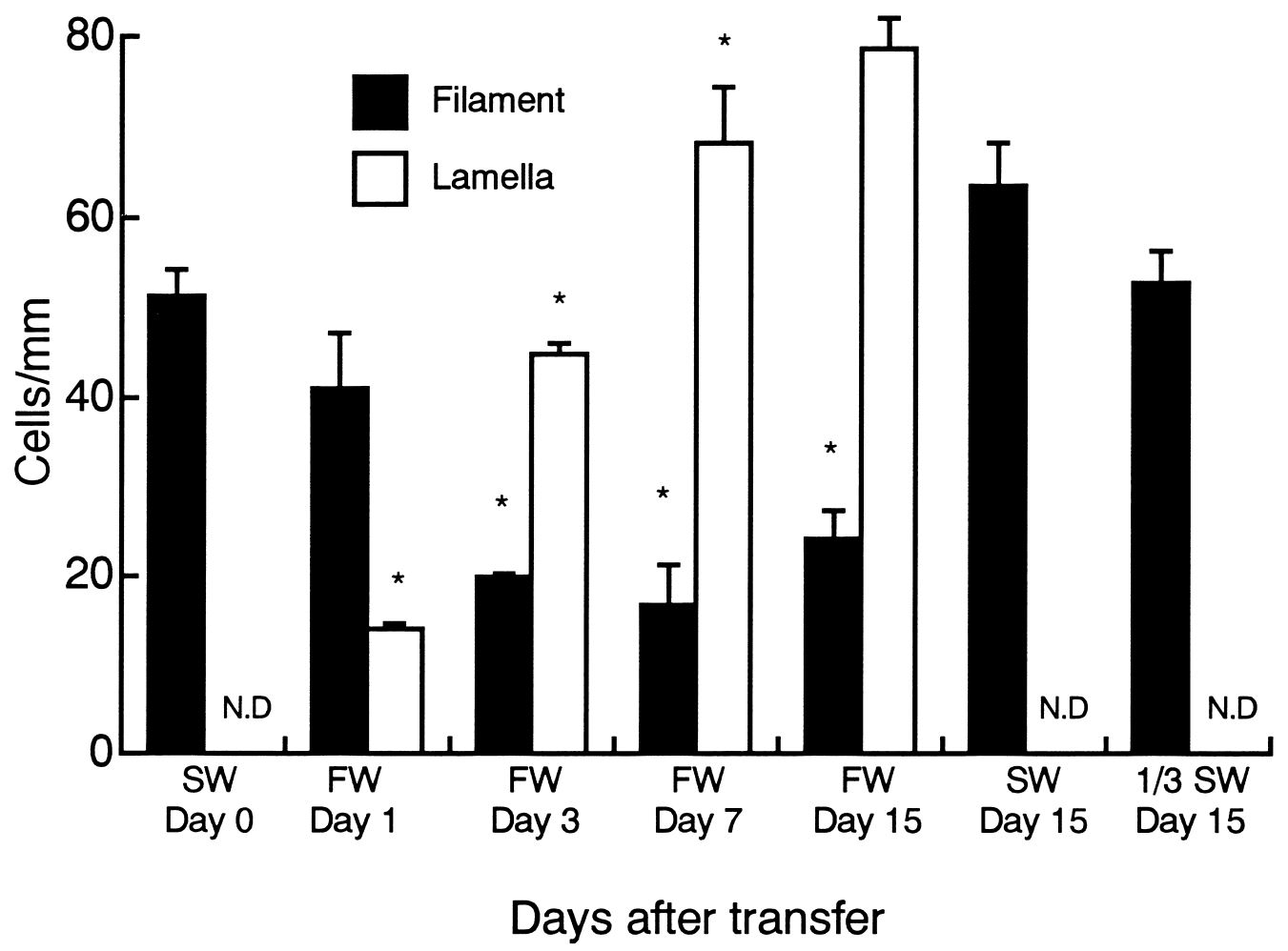

Fig. 4. Changes in chloride cells density following transfer from SW to FW, $1 / 3 \mathrm{SW}$ and $\mathrm{SW}$ in juvenile Japanese sea bass. Values are means \pm S.E.M. $(n=4)$. Significantly different at ${ }^{*} p<0.001$, from the value on day 0 .

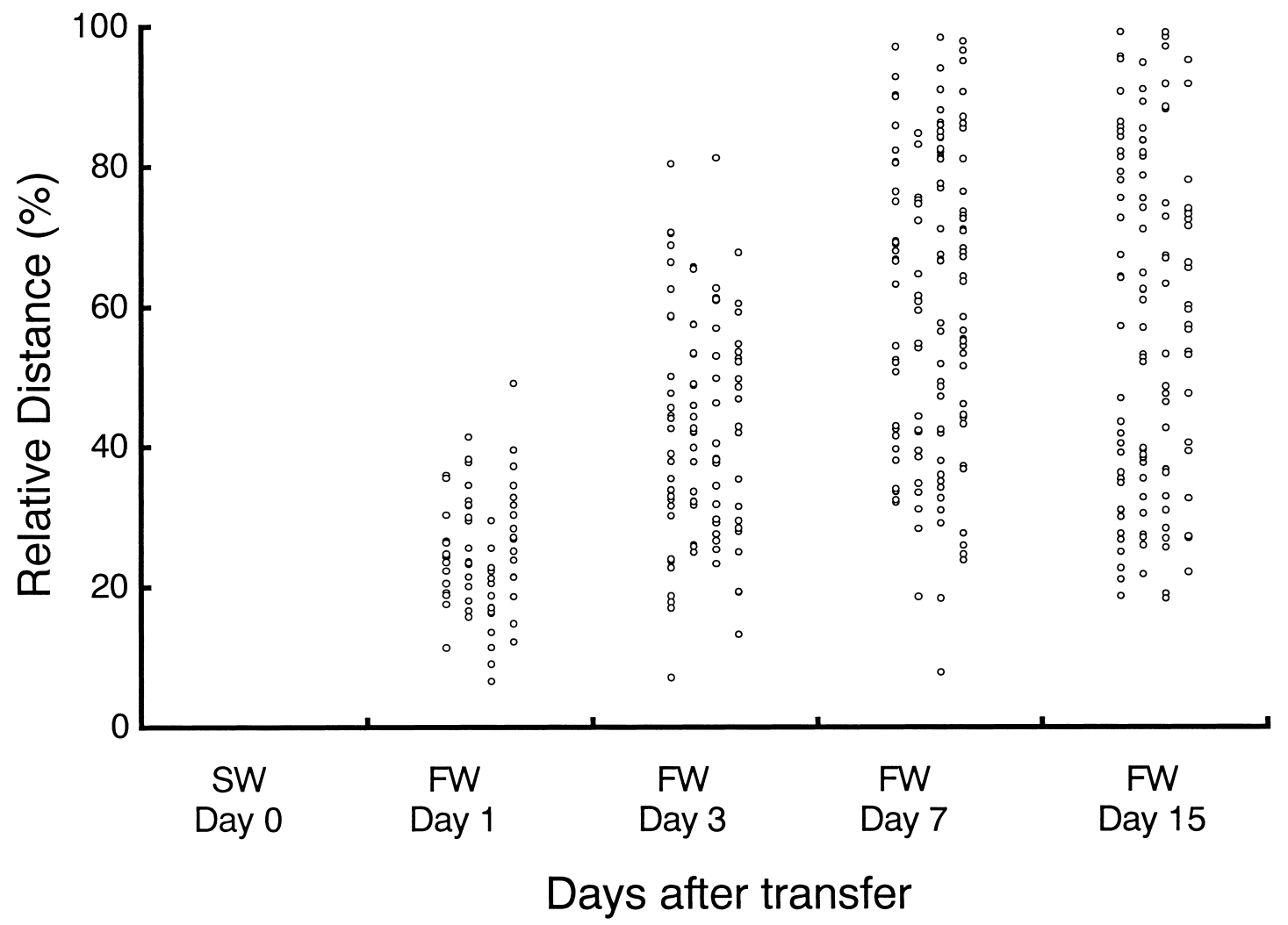

Fig. 5. Changes in distribution of lamellar chloride cells. See Fig. 1 for the relative distance. 
filaments.

In the present study, appearance of chloride cells in the lamellae was demonstrated in juvenile sea bass transferred to FW. Our findings indicate the importance of lamellar chloride cells in FW adaptation. The function of lamellar chloride cells in sea bass is probably ion uptake from dilute environmental water, as is expected in salmonids and eel. Considering the unique FW adaptability during their juvenile stage, sea bass would provide a valuable experimental model in examining the activation and production mechanisms of chloride cells in gill lamellae.

The mechanisms of the alteration in chloride cell distribution and number, as well as of putative changes in their functions may be under hormonal control. FW-specific B chloride cells (Pisam et al., 1993) were induced in salt wateradapted tilapia Oreochromis niloticus by prolactin, a hormone important for FW adaptation. In vitro treatment with cortisol, a SW-adapting hormone, increased the number and size of chloride cells in the opercular membrane (McCormick, 1990), and chloride cells in the yolk-sac membrane also increased their size in response to cortisol treatment both in vivo and in vitro (Ayson et al., 1995). Moreover, Uchida et al. (1998) demonstrated intense immunoreaction to cortisol receptor on lamellar chloride cells in chum salmon. On the contrary, the decrease in the chloride cell size following prolactin injections to SW-adapted tilapia was reported by Herndon et al. (1991). Although at present no information is available on hormonal control of gill chloride cells in sea bass, development of lamellar chloride cells in FW is likely to be regulated by endocrine systems.

\section{ACKNOWLEDGEMENTS}

We thank Mr. N. Makino, Chiba Prefectural Tokyo Bay Fish Farming Center, for supplying sea bass eggs. We are grateful to Dr. K. Soyano, Nagasaki University, for supplying anti- $\mathrm{Na}^{+}, \mathrm{K}^{+}$-ATPase. We would like to thank Mr. J. Hiroi, Kyoto University, for his technical advice. This study was supported in part by grants-in-aid from the Ministry of Education and from Cooperative Program (No. 27, 1998) of Ocean Research Institute, University of Tokyo.

\section{REFERENCES}

Avella M, Bornancin M (1990) Ion fluxes in the gill of freshwater and seawater salmonid fish. In "Animal Nutrition and Transport Processes. 2. Transport, Respiration and Excretion: Comparative and Environmental Aspects" Ed by JP Truchot, B Lahlou, Karger, Basel, Comparative Physiology Vol 6 pp1-13

Ayson FG, Kaneko T, Hasegawa S, Hirano T (1995) Cortisol stimulates the size and number of mitochondrion-rich cells in the yolksac membrane of embryos and larvae of tilapia (Oreochromis mossambicus) in vitro and in vivo. J Exp Zool 272: 419-425

Evans DH (1984) The role of gill permeability and transport mechanisms in euryhalinity. In "Fish Physiology Vol XB" Ed by WS Hoar, DJ Randall, Academic Press, New York, pp 239-283

Foskett JK, Scheffey C (1982) The chloride cell: Definitive identification as the salt-secretory cell in teleosts. Science 215 : 164-166

Flik G, Klaren PHM, Schoenmakers TJM, Bijvelds MJC, Verbost PM, Wendelaar Bonga SE (1996) Cellular calcium transport in fish: unique and universal mechanisms. Physiol Zool 69: 403-417
Flik G, Verbost PM, Wendelaar Bonga SE (1995) Calcium transport processes in fishes. In "Cellular and Molecular Approaches to Fish Ionic Regulation" Ed by CM Wood, TJ Shuttleworth, Academic Press, New York, pp 317- 342

Fujita S, Kinoshita I, Takahashi I, Azuma K (1988) Seasonal occurrence and food habits of larvae and juveniles of two temperate basses in the Shimanto estuary, Japan. Japan J Ichthyol 35: 365370

Herndon TM, McCormick SD, Bern HA (1991) Effects of prolactin on chloride cells in opercular membrane of SW-adapted tilapia. Gen Comp Endocrinol 83: 283-289

Hsu SM, Raine L, Franger H (1981) Use of avidin-biotin-peroxidase complex $(A B C)$ in immunoperoxidase techniques: A comparison between $A B C$ and unlabeled antibody (PAP) procedures. $J$ Histochem Cytochem 29: 577-580

Karnaky KJ Jr, Kinter LB, Kinter WB, Stirling CE (1976) Teleost chloride cell.II. Autoradiographic localization of gill $\mathrm{Na}^{+}, \mathrm{K}^{+}$-ATPase in killifish Fundulus heteroclitus adapted to low and high salinity environments. J Cell Biol 70: 157-177

Laurent P, Dunel S (1980) Morphology of gill epithelia in fish. Am J Physiol 238: 147-159

Laurent P, Dunel-Erb S, Chevalier C, Lignon J (1994) Gill epithelial cells kinetics in freshwater teleost, Onchorhynchus mykiss during adaptation to ion-poor water and hormonal treatments. Fish Physiol. Biochem. 13: 353-370

Li J, Eygensteyn J, Lock RAC, Wendelaar Bonga SE, Flik G (1997) $\mathrm{Na}^{+}$and $\mathrm{Ca}^{2+}$ homeostatic mechanisms in isolated chloride cells of the teleost Oreochromis mossambicus analysed by confocal laser scanning microscopy. J Exp Biol 200: 1499-1508

Matsumiya Y, Mitani T, Tanaka M (1982) Changes in distribution pattern and condition coefficient of the juvenile Japanese sea bass with the Chikugo River ascending. Nippon Suisan Gakkaishi 48: 129-138

Matsumiya Y, Masumoto H, Tanaka M (1985) Ecology of ascending larval and early juvenile Japanese sea bass in the Chikugo Estuary. Nippon Suisan Gakkaishi 51: 1955-1961

McCormick SD (1990) Cortisol directly stimulates differentiation of chloride cells in tilapia opercular membrane. Am J Physiol 259: 857-863

McCormick SD (1995) Hormonal control of gill $\mathrm{Na}^{+}, \mathrm{K}^{+}-$ATPase and chloride cell function. In "Cellular and Molecular Approaches to Fish lonic Regulation" Ed by CM Wood, TJ Shuttleworth, Academic Press, New York, pp 285-315

McCormick SD, Hasegawa S, Hirano T (1992) Calcium uptake in the skin of a freshwater teleost. Proc Natl Acad Sci USA 89: 36353638

Ochiai A, Tanaka M (1986) Japanese sea bass. In "Ichthyology (2nd part)" Koseisha-koseikaku, Tokyo, pp 675-681 (in Japanese)

Perry SF, Goss GG, Laurent P (1992) The interrelationships between gill chloride cell morphology and ionic uptake in four freshwater teleosts. Can J Zool 70: 1775-1786

Pisam M, Rambourg A (1991) Mitochondria rich cells in the gill epithelium of teleost fishes: An ultrastructural approach. Int Rev Cytol 130: 191-232

Pisam M, Caroff A, Rambourg A (1987) Two types chloride cells in the gill epithelium of a freshwater-adapted euryhaline fish: Lebistes reticulatus; their modifications during adaptation to SW. Am J Anat 179: 40-50

Pisam M, Boeuf G, Prunet P, Rambourg A (1990) Ultrastructural features of mitochondria-rich cells in stenohaline freshwater and seawater fishes. Am J Anat 187: 21-31

Pisam M, Auperin B, Prunet P, Rentier-Delrue F, Martial J, Rambourg A (1993) $\alpha$ and $B$ chloride cells in the gill epithelium of the saltwater adapted tilapia "Oreochromis niloticus". Anat Rec 235: 275284

Sasai S, Kaneko T, Hasegawa S, Tsukamoto K (1998) Morphological alteration in two types of gill chloride cells in Japanese eel 
(Anguilla japonica) during catadromous migration. Can J Zool (in press)

Tanaka M (1997) Inshore migration of coastal marine fish in relation to metamorphosis. Kaiyo Monthly 29: 199-204 (in Japanese)

Uchida K, Kaneko T (1996) Enhanced chloride cell turnover in the gills of chum salmon fry in seawater. Zool Sci 13, 655-660

Uchida K, Kaneko T, Yamauchi K, Hirano T (1996) Morphometrical analysis of chloride cell activity in the gill filaments and lamellae and changes in $\mathrm{Na}^{+}, \mathrm{K}^{+}$-ATPase activity during seawater adaptation in chum salmon fry. J Exp Zool 276:193-200

Uchida K, Kaneko T, Tagawa M, Hirano T (1998) Localization of cortisol receptor in branchial chloride cells in chum salmon fry. Gen Comp Endocrinol 109:175-185
Ura K, Soyano K, Omoto N, Adachi S, Yamauchi K (1996) Localization of $\mathrm{Na}^{+}, \mathrm{K}^{+}$-ATPase in tissues of rabbit and teleosts using antiserum directed against a partial sequence of the $\alpha$-subunit. Zool Sci 13: 219-227

Zadunaiskey JA (1984) The chloride cell: The active transport of chloride and the paracellular pathways. In "Fish Physiology Vol XB" Ed by WS Hoar, DJ Randall, Academic Press, New York, pp 129-176

(Received June 25, 1998 / Accepted November 8, 1998) 